\title{
PENGEMBANGAN VARIAN PRODUK DENGAN PELATIHAN FORMULASI KRIM KEFIR SUSU KAMBING SEBAGAI PENCERAH KULIT
}

\author{
Uswatun Chasanah $^{1}$, Dyah Rahmasari ${ }^{2}$ \\ ${ }^{1,2)}$ Program Studi Farmasi, Fakultas Ilmu Kesehatan, Universitas Muhammadiyah Malang \\ uswatun@umm.ac.id.
}

\begin{abstract}
The kefir of goat's milk has good benefits for skin health. There are goat milk kefir creams on the market, but tutorials to make cream of goat's milk kefir are not available on social media, even though it useful by the goat milk producer who wants to develop product variations. Training for goat's milk kefir cream formulation had done, partner of this activity is a goat milk producing community. This activity begins with a theoretical and technical explanation of the making of goat's milk kefir cream then continues with training activities, and video tutorials were uploaded to social media, too. It has been an increase in the knowledge and skills of the Partners. This activity is an inspiration for Partners to add product variants, especially making kefir cream.
\end{abstract}

Keywords: Formulating, goat milk kefir cream, training

\begin{abstract}
Abstrak
Kefir susu kambing memiliki manfaat yang baik untuk kesehatan kulit. Krim kefir susu kambing sudah banyak dijual di pasaran, namun tutorial tentang cara pembuatannya masih sulit ditemukan pada media social, sementara ketrampilan ini sangat dibutuhkan oleh masyarakat yang berkecimpung pada produksi berbahan dasar susu kambing. Telah dilakukan kegiatan Ilmu Bagi Masyarakat (IbM) berupa pelatihan formulasi krim kefir susu kambing kepada sekelompok masyarakat penghasil susu kambing dan masyarakat umum. Kegiatan ini diawali dengan penjelasan teori dan teknis tentang pembuatan krim kefir susu kambing kemudian dilanjutkan dengan kegiatan pelatihan, dan bagi masyarakat umum disiapkan video tutorial pembuatan krim kefir susu kambing yang telah diunggah pada media social. Dari hasil kegiatan ini didapatkan peningkatan pengetahuan dan ketrampilan pihak Mitra. Kegiatan ini dapat menjadi inspirasi bagi Mitra untuk dapat menambah varian produk berupa krim kefir susu kambing.
\end{abstract}

Kata kunci: formulasi, krim kefir susu kambing, pelatihan

\section{PENDAHULUAN}

yang terletak di Kecamatan Junrejo, Kota Batu, Jawa Timur, Indonesia. Penduduk desa ini sebagaian besar adalah petani dan sebagian kecil adalah peternak. Sebagai Mitra Pengabdian Kepada Masyarakat adalah mereka yang berprofesi sebagai peternak kambing ettawa yang menghasilkan susu kambing segar. Produk susu kambing segar yang dihasilkan di daerah tersebut juga telah dikembangkan menjadi yogurt, kefir, dan sabun padat (Chasanah, 2020)(Sujono et al., 2019).

Kefir adalah produk olahan susu yang didapatkan melalui proses fermentasi oleh berbagai jenis mikroba yaitu bakteri penghasil asam laktat 
(BAL), bakteri penghasil asam asetat, dan khamir (Rosa et al., 2017). Dalam kefir terkandung Alpha Hydroxy Acid (AHA) yang mampu mencerahkan kulit dan mencegah/ menyembuhkan jerawat (Chen et al., 2006), kefir juga merupakan antioksidan alami yang memiliki khasiat sebagai antiaging (Gaware et al., 2011).

Pemanfaat kefir sebagai bahan perawatan kulit sudah dikenal luas di masyarakat bahkan kosmetika yang memanfaatkan kefir sebagai bahan aktif sudah banyak. Tingginya permintaan bahan baku kefir untuk diolah menjadi kosmetika mengusik Mitra untuk meningkatkan ketrampilan membuat sediaan krim berbahan kefir, namun tutorial tentang pembuatan krim kefir susu kambing masih sulit ditemukan pada media social misalnya U-Tube, face book, instagram, dan lain-lain. Menindak lanjuti keinginan dari Pihak Mitra tersebut, maka diadakan pelatihan tentang pembuatan sediaan krim berbahan kefir susu kambing sebagai tema dari kegiatan pengabdian ini.

\section{METODE}

Kegiatan Pengabdian masyarakat ini dilakukan dengan Teknik Pelatihan secara langsung atau tatap muka yang dilakukan di kota Batu pada bulan Agustus tahun 2020. Sebagai kelengkapan pelatihan telah disiapkan alat dan bahan yang ditunjukkan pada Gambar 1 dan Gambar 2. Sedangkan untuk formulasi adalah merupakan modifikasi tugas akhir dari mahasiswa S1 Farmasi Universitas Muhammadiyah Malang. Untuk pembahasan adalah berupa deskrispi berlangsungnya kegiatan pelatihan.

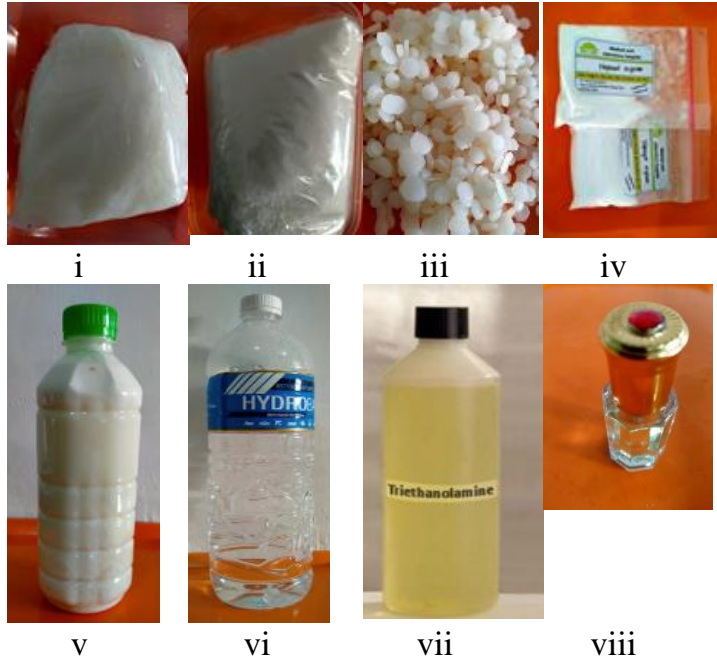

Gambar 1. Bahan baku krim kefir yang terdiri dari vaselinum album (i), asam stearate (ii), Cera alba (iii), Nipagiin \& nipasol(iv), kefir (v), Tri etanol amin (vi), parfum (vii).

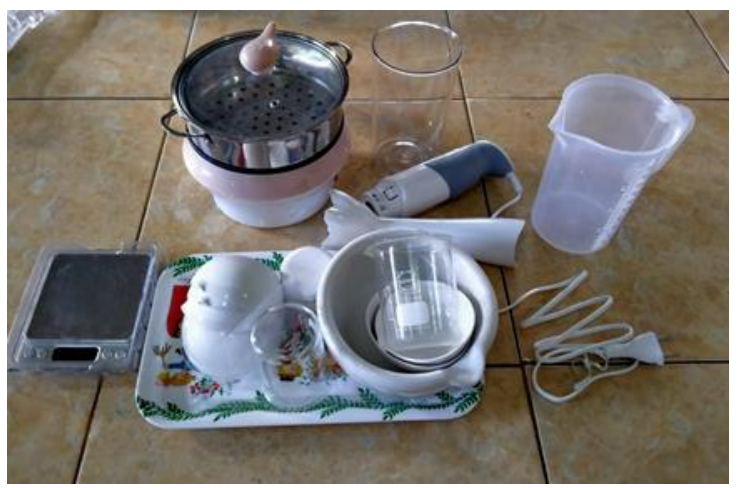

Gambar 2. Peralatan untuk membuat krim yang terdiri dari timbangan digital, stamper dan mortar, cawan porselin, beaker glass, handblender/mixer, gelas plastik, pot krim

Pada prinsipnya formulasi krim kefir ini adalah menggunakan basis vanishing cream. Formulasi krim kefir susu kambing yang digunakan pada kegiatan pelatihan ada pada Tabel 1 .

Table 1. Formula krim kefir

\begin{tabular}{lr}
\hline \multicolumn{1}{c}{ Bahan } & $\begin{array}{c}\text { Komposisi } \\
(\mathbf{\% b} / \mathbf{b})\end{array}$ \\
\hline Kefir susu & \\
kambing & 20,0 \\
Cera alba & 1,0 \\
Vaselinum albim & 7,5 \\
Asam stearat & 15,0 \\
Tri etanol amin & 1,5
\end{tabular}


Uswatun Chasanah, dkk. Pengembangan Varian Produk Dengan Pelatihan Formulasi ...

\begin{tabular}{|c|c|c|}
\hline Propilen glikol & & 10,0 \\
\hline Nipagin & & 0,02 \\
\hline Nipasol & & 0.02 \\
\hline Parfum & & q.s \\
\hline Air murni & sampai & 100,0 \\
\hline
\end{tabular}

\section{HASIL DAN PEMBAHASAN}

Telah dilakukan kegiatan pengabdian kepada masyarakat berupa Ilmu Bagi Masyarakat (IbM) tentang formulasi krim kefir susu kambing yang dapat dimanfatkan sebagi krim pencerah kulit. Kegiatan ini dihadiri oleh 13 peserta yang terdiri dari penghasil/ produsen susu kambing segar ettawa dan sebagian masyarakat umum. Menyesuaikan pada saat kegiatan adalah merupakan masa pandemi Covid 19, maka pelaksanaan kegiatan mengikuti prosedur tetap kesehatan yakni menerapkan social distancing dan menggunakan alat pelinding diri bagi semua peserta pelatihan sebagaimana ditunjukkan pada Gambar 3.

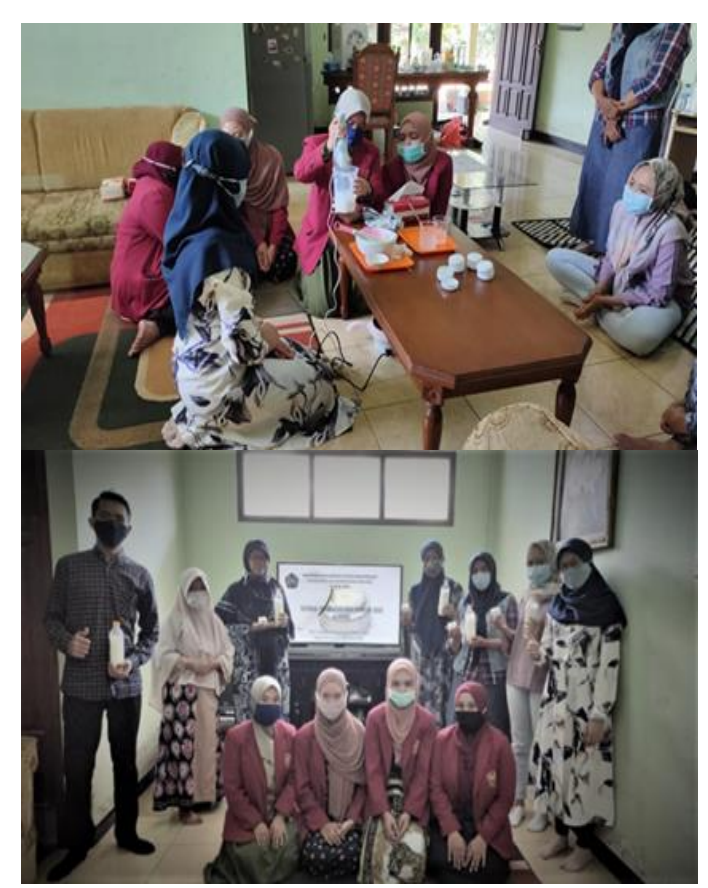

Gambar 3. Kegiatan pelatihan

Diawali dengan penjelasan teori oleh tim pengusul tentang formulasi krim kefir beserta fungsi dari setiap bahan dalam formulasi, juga disampaikan trik dan tips agar berhasil melakukan formulasi, kemudian dilanjutkan dengan praktek pembuatan krim kefir oleh masing-maisng peserta dengan dibantu oleh tim pendamping adalah mahasiswa S1 Farmasi Universitas Muhammadiyah Malang yang sedang menempuh tugas akhir. Kepada setiap peserta diberikan satu paket bahan yang sudah ditimbang sebelumnya sehingga tinggal dicampur saja.

Setelah selesai kegiatan praktik pembuatan krim, maka dilakukan evaluasi dari krim yang telah dibuat oleh para peserta. Didapatkan krim berwarna putih yang lembut dengan aroma khas kefir seperti ditunjukkan pada Gambar 4.

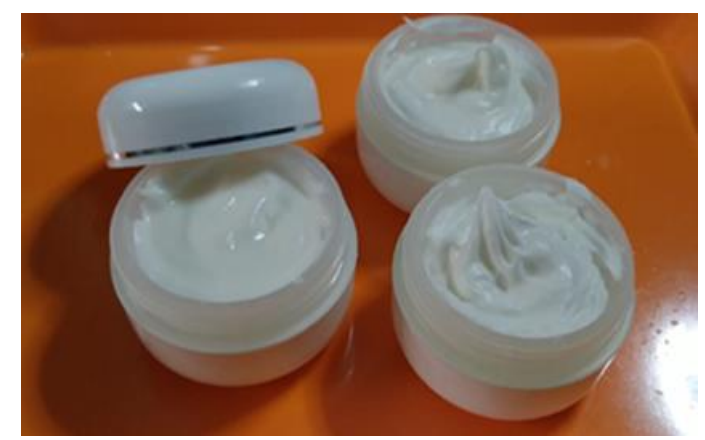

Gambar 4. Krim kefir susu kambing

Bahwa ketrampilan untuk membuat krim kefir dirasa perlu juga untuk diketahui masyarakat luas yang tertarik untuk membuatnya, dan bagi peserta pelatihan sebagai pengingat materi pelatihan, oleh sebab itu dibuat video tutorial yang telah diunggah di kanal U-Tube dengan tautan berikut ini:

https://www.youtube.com/watch?v=cQ kfcDT93ng\& $\mathrm{t}=1 \mathrm{~s}$

Sebagai cuplikan dari video yang telah diunggah di media social seperti ditunjukkan pada Gambar 5. 


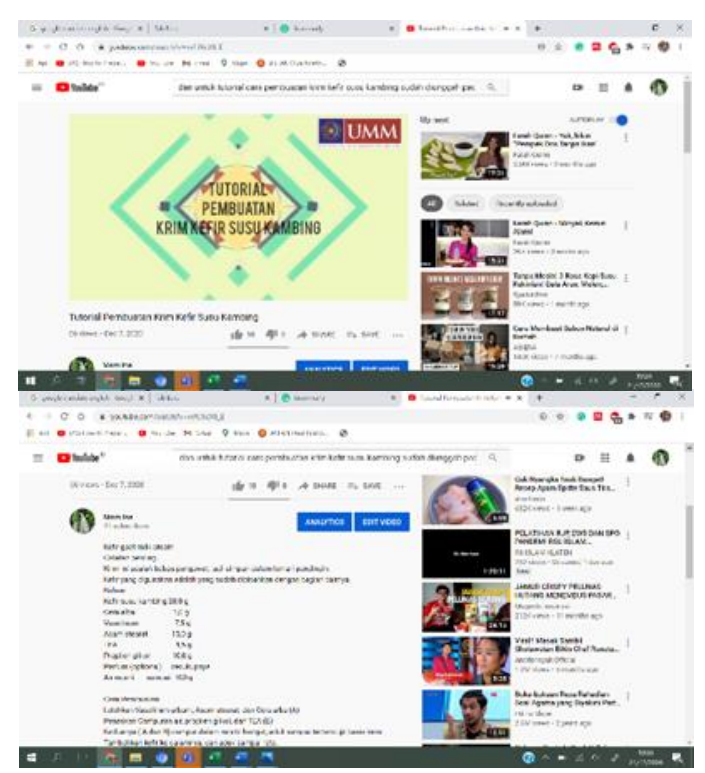

Gambar 5. Cuplikan video U-tube

Video yang diunggah durasinya sangat singkat, hanya 2 menit 35 detik saja, oleh sebab itu pada video telah dilengkapi pula dengan deskrispsi formula krim kefir sehingga memudahkan pemirsa untuk memahami video yang telah ditayangkan.

Untuk mencapai hasil yang maksimal dalam mempelajari sesuatu maka ada tiga aspek yang harus dikembangkan adalah aspek kognitif, afektif, dan psikomotorik. Ranah kognitif mencakup pengetahuan, ranah afektif yakni mengenai pemahaman dan bagaimana bersikap, sedangkan ranah psikomotorik adalah praktik atau kemampuan individu dalam melakukan apa yang telah dia pelajari (Huitt, 2011). Pelatihan yang dilakukan secara langsung akan memberikan hasil yang optimal karena dengan praktek secara langsung masing-masing peserta akan mendapatkan kesan/ingatan yang lebih baik jika dibandingkan dengan mendengar dan atau melihat saja. Dengan praktek secara langsung mereka akan tahu bagian titik kritis proses pembuatan krim, misalnya urutan pencampuran, alasan penimbangan/ penakaran bahan yang harus dilakukan akurat, penentuan suhu pencampuran, kecepatan pengadukan, dan hal tehnis lain yang hanya bisa dipahami dengan praktek secara langsung.

Dari hasil evaluasi krim yang telah dibuat oleh peserta dapat dinyatakan bahwa semua peserta sudah berhasil membuat krim berbahan kefir susu kambing. Krim yang didapatkan berupa massa semipadat berwarna putih yang homogen, tidak berbusa, mudah dioleskan, tidak berminyak, bau aromatik khas kefir dengan $\mathrm{pH}$ cenderung asam. Untuk aroma yang khas kefir, jika tidak diinginkan dapat ditutupi dengan menambahkan parfum secukupnya.

Perlu diketahui bahwa krim kefir mengandung asam laktat yang dalam hal ini juga sebagai bahan aktif, oleh sebab itu penyimpanan krim kefir disarankan untuk disimpan di lemari pendingin.

Bahwa formula yang disampaikan pada pelatihan ini adalah formula dasar krim kefir susu kambing yang masih ada kemungkinan untuk dikembangkan, misal dengan ditambahkan ekstrak kulit buah manggis, ekstrak kulit buah delima, ekstrak green tea, atau bahan lain sehingga dapat meningkatkan manfaat/khasiat krim kefir sebagai krim pencerah.

Sebagai kendala tindak lanjut setelah diproduksinya krim kefir ini adalah terkait pemasarannya. Krim kefir adalah merupakan golongan kosmetika sehingga untuk dapat dijual pada masyarakat luas masih diperlukan perijinan dari pemerintah (Endang et al., 2015), sehingga untuk sementara disarankan kepada pihak Mitra dibuat sebagai produk home made tanpa merk supaya bisa ditawarkan pada lingkup terbatas sambil dievaluasi prospek ke depannya. 
Uswatun Chasanah, dkk. Pengembangan Varian Produk Dengan Pelatihan Formulasi ...

\section{SIMPULAN}

Kegiatan pelatihan formulasi krim kefir susu kambing sangat bermanfaat bagi peserta/Mitra karena telah menambah pengetahuan dan meningkatkan ketrampilan mereka. Diharapkan pihak Mitra dapat mengembangkan formulasi ini sehingga berpeluang untuk dipasarkan lebih luas.

\section{UCAPAN TERIMA KASIH}

Penulis mengucapkan terima kasih kepada Direktorat Penelitian dan Pengabdian Masyarakat Universitas Muhammadiyah Malang yang telah memberi dukungan financial terhadap pengabdian ini.

\section{DAFTAR PUSTAKA}

Chasanah, U. (2020). IbM Pelatihan Formulasi Sabun Padat Susu Kambing Science for the Community: Training on Goat Milk Solid Soap Formulation. PengabdianMu: Jurnal Ilmiah Pengabdian Kepada Masyarakat, 5(2), 133-137. https://doi.org/10.33084/penga bdianmu.v5i2.1035

Chen, M. J., Liu, J. R., Sheu, J. F., Lin, C. W., \& Chuang, C. L. (2006). Study on skin care properties of milk kefir whey. Asian-Australasian Journal of Animal Sciences. https://doi.org/10.5713/ajas.20 $\underline{06.905}$
Endang, D., Apt, P., Kepala, M. M., \& Besar, B. (2015). Regulasi Kosmetika dan Kosmetika Obat. 37. https://stikesmukla.ac.id/SemN as/Regulasi-Kosmetika-danKosmetika-Obat/2520

Gaware, V., Kotade, K., Dolas, R., \& Dhamak, K. (2011). ewsletter Gaware et al . THE MAGIC OF KEFIR: A REVIEW Gaware et al . Historyo of Kefir. 386, 376-386. https://pharmacologyonline.sila e.it/files/newsletter/2011/vol1/ 034.gaware.pdf

Huitt, W. (2011). Bloom et al.'s taxonomy of the cognitive domain. Educational Psychology Interactive. http://www.edpsycinteractive.o rg/topics/cognition/bloom.html

Rosa, D. D., Dias, M. M. S., Grześkowiak, Ł. M., Reis, S. A., Conceição, L. L., \& Peluzio, M. D. C. G. (2017). Milk kefir: Nutritional, microbiological and health benefits. In Nutrition Research Reviews.

https://doi.org/10.1017/S09544 22416000275

Sujono, S., Khotimah, K., \& Kusuma, H. (2019). Usaha PPUPIK Pembibitan Kambing Perah Unggul dan Olahan Produk Susu Kambing. Jurnal SOLMA. https://doi.org/10.29405/solma. v8i2.3530 